\title{
Chemical, electrochemical and tribological study of various olive oils and their behaviour on steel
}

Henrikas Cesiulis $^{1^{*}}$,

Albinas Žilinskas ${ }^{1,2}$,

Juozas Padgurskas ${ }^{3}$,

Raimondas Kreivaitis ${ }^{3}$,

Raimundas Rukuiža ${ }^{3}$

${ }^{1}$ Faculty of Chemistry and Geosciences,

Vilnius University,

Naugarduko St. 24, 03225 Vilnius, Lithuania

${ }^{2}$ Department of Chemistry and Bioengineering,

Vilnius Gediminas Technical University,

Sauletekio Ave. 11, 10223 Vilnius, Lithuania

${ }^{3}$ Institute of Power and

Transport Machinery Engineering,

Aleksandras Stulginskis University,

Studentu St. 15, 53362 Akademija,

Kaunas District, Lithuania
The influence of different chemical composition and physical properties of olive oils, produced from various districts in Morocco with various acidic numbers (from 1.76 to 18.01), on their tribological performance and corrosion protection has been investigated. The chemical composition was determined by means of IR, ${ }^{1} \mathrm{H}$ and ${ }^{13} \mathrm{C}$ NMR spectroscopy. The investigated olive oils show small quantitative and qualitative differences between each other (the amount of free fatty acids and the composition of fatty acids in triglycerides). The spectroscopic data let us unambiguously determine in general that the main fatty acids in oils are saturated palmitic and/or stearic acids, unsaturated oleic and linoleic acids except linolenic acid. The oxidation stability of oils was estimated. The contact angle measurements and electrochemical impedance spectroscopy data show that all films of olive oils on the surfaces of steels are porous; therefore, the values of corrosion inhibition efficiency are relatively low and ranged from 57 to $75 \%$. The variations of friction coefficients and their mean values, the wear of steel covered by olive oils were estimated. The oils with the highest oxidation stability also show better lubricating properties.

Keywords: olive oil, electrochemical impedance spectroscopy, friction coefficient, work of adhesion, wear, NMR spectroscopy, contact angle

\section{INTRODUCTION}

Olive oil is concerned as an environmentally safe and biodegradable lubricant, which can be used in many mechanical systems, particularly in agriculture engineering [1]. Regardless the variety of vegetable oils are concerning for use in tribosystems (e.g. [2-4]), manufacturers and blenders of these products promote biodegradables for use based on the importance of biodegradability and nontoxicity. However, performance issues like oxidation stability, antiwear protection, hydrolytic stability and viscosity are poorly presented in literature [5]. However, less or more comprehensive investigations are carried out on rapeseed oil [6-10].

\footnotetext{
*Corresponding author. Email: henrikas.cesiulis@chf.vu.lt
}

Indeed, the physical and chemical properties of biological oils play an important role during their operation with industrial raw and food processing equipment. Food-grade lubricants must offer protection of internal surfaces to control friction, wear, corrosion, heat and deposits taking into consideration the possibility of an incidental food contact. The impact of corrosion on the iron surface, low thermal and oxidation stability of biological oils limits the longevity of food-grade equipment and possibility of the use of biooils as lubricants [11, 12].

Water and other oil pollutants are important for friction surface corrosion. The oxidation of bio-oils causes its polymerization and degradation. During the latter the decomposition products appear which may be volatile, start corrosion and reduce the oil lubricating properties. The oxidation 
rate is determined by the temperature, the contact of metals with oil, the amount of water and oxygen in oil. The effect of the temperature is great - with its increment by $10^{\circ} \mathrm{C}$ the oxidation rate may rise three times 13,14 .

The lubrication properties of vegetables are strongly related to their chemical structure and content. Natural biological oils, specifically olive oils, consist of triglycerides which consist of glycerol and little amounts of free fatty acids of different chain length [15-17]. Fatty acids of triglyceride may be monosaturated and polyunsaturated. Furthermore, different fats may be different in their content [11, 18]. The general chemical structure of oils would be represented in Fig. 1.

The fatty acid composition of the oil determines its characteristics. The presence of double bonds makes the oil liquid, but also increases oxidative instability. Oils highly enriched in monounsaturated fatty acids have improved lubricity and oxidative stability [19]. Major fatty acids in such compositions are palmitic acid (7.5 to $20 \%$ ), stearic acid (0.5 to $5 \%$ ), oleic acid ( 55 to $83 \%$ ), linoleic acid (3.5 to $21 \%$ ) and linolenic acid (0 to 1.5\%). As the chemical composition of olive oils may vary, it supposes the variety of interactions with materials even in the case of the same type of oils. For example, tribological tests of wear resistance properties of differently produced rapeseed oils show that unrefined rapeseed oil has better wear resistance as compared to that of refined oil [20]. In this study we explored the influence of different chemical composition and physical properties of olive oils produced from various districts in Morocco on their tribological performance and corrosion protection.

\section{EXPERIMENTAL}

The IR spectra were registered with a Perkin-Elmer Spectrum BX II spectrometer (oil film). The ${ }^{1} \mathrm{H}$ and ${ }^{13} \mathrm{C}$ NMR spectra were determined with a Bruker Ascend 400 spectrometer
(400 MHz frequency for ${ }^{1} \mathrm{H}$ NMR and $100 \mathrm{MHz}$ for ${ }^{13} \mathrm{C} \mathrm{NMR}$ ). The chemical shift values were represented in a ppm scale, as solvent $\mathrm{CDCl}_{3}$ was used.

Acid numbers were determined following the standard EN ISO 660:2009 "Animal and Vegetable Fats and Oils. Determination of Acid Value and Acidity".

The surface tension and the contact angle of investigated olive oils were determined using a PC-controllable Attension Theta optical tensiometer. The volume of drops in all experiments was $<7 \mu \mathrm{L}$.

The electrochemical corrosion tests were performed by means of AUTOLAB302, the software GPES was used for the determination of polarization curves, and the software FRA was applied for the recording and analysis of electrochemical impedance spectra in a three-electrode cell with a horizontally placed working electrode having the working area $0.38 \mathrm{~cm}^{-2}$ in a $0.1 \mathrm{M} \mathrm{Na}_{2} \mathrm{SO}_{4}$ solution at $20^{\circ} \mathrm{C}$; a more detailed description of the used setup is provided in [21]. The oil films of fixed thickness $(13 \mu \mathrm{m})$ were deposited on the steel electrode before tests. In order to obtain the oil film of a particular thickness and even distribution onto the entire area of the electrode, the corresponding amount of oil stock solution ( $100 \mu \mathrm{L}$ oil in $50 \mathrm{~mL}$ of diethyl ether), dependently on the oil density, was applied on the electrode and kept until all the amount of ether evaporated ( $20 \mathrm{~min})$.

In addition, copper corrosion tests were performed in accordance with the standard method LST EN ISO 2160:1998. The prepared plates of copper were hold in the investigated lubricant at $100^{\circ} \mathrm{C}$. The test duration was $3 \mathrm{~h}$. To avoid any fatty residues on the specimen surface it was washed with $\mathrm{n}$-heptane before and immediately after the test. The obtained results were estimated using standard reference plates, comparing them with those obtained during the tests.

The accelerated oxidation tests of olive oils were conducted by using the Rancimat 743 equipment. The tests were

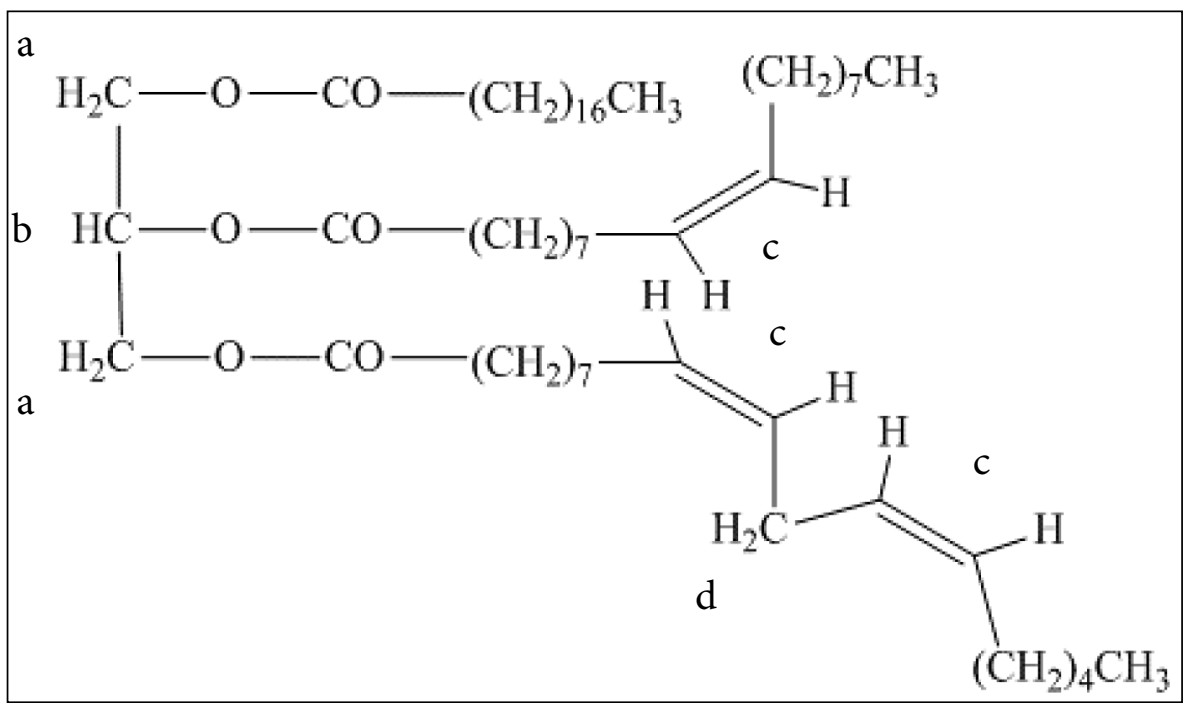

Fig. 1. The general chemical structure of oil. For details see the text below 
performed in accordance with the ISO 6886:2006 standard method. The amount of the sample was $2.5 \mathrm{~g}$. The test temperature was $100^{\circ} \mathrm{C}$, the dry air with $7 \mathrm{l} / \mathrm{h}$ flow rate was blown through the sample. The exiting air, including volatile oxidation products, was directed to bubble through the vessel with deionized water, whose electrical conductivity was monitored. With the onset of oxidation, rapid production of volatile degradation products begins, the so-called "induction period" (IP). During this test, volatile products dissolve in water and cause a rapid increase of electrical conductivity monitored by the Rancimat apparatus; the longer induction period the better oxidation stability.

The tribological tests were performed with a four balls friction test machine MAST-1 assembled and modernized at Aleksandras Stulginskis University. The balls of a $12.7 \mathrm{~mm}$ diameter were made of $100 \mathrm{Cr} 6$ bearing steel $\left(E=21.98 \cdot 10^{4} \mathrm{MPa} ; v=0.3\right)$, the oil sample was $22 \mathrm{ml}$, the load $50 \mathrm{~N}$, the rotation speed was $1420 \mathrm{rpm}$, and the duration of tests was $1 \mathrm{~h}$. The testing procedure was adapted from the standard DIN 51350-3 [22]. The wear reducing efficiency of lubricants was evaluated based on the area of wear spots measured by a microscope. The ability of oil to reduce friction losses was estimated by measuring of the friction torque during the tests.

\section{RESULTS AND DISCUSSION}

\section{Chemical composition of oils}

The detailed chemical composition of four examples of olive oils from Morocco (Tourough, Ifri, Khongue and Ohejidid localities) was studied by various types of spectroscopy (IR, ${ }^{1} \mathrm{H}$ and ${ }^{13} \mathrm{C}$ NMR spectra).
The IR spectra of all four oils were identical except one detail in the spectrum of Tourough oil: we observed an obvious slight additional characteristic vibratory band of the acid carbonyl group (COOH) at $1712 \mathrm{~cm}^{-1}$ near the characteristic of ester carbonyl group (COOR) broad band at $1746-1747 \mathrm{~cm}^{-1}$ (Fig. 2). It showed that Tourough oil contains considerably more free acids in comparison to other three oils. This is confirmed also by the highest acid value determined in separate experiments for this oil (see Table 1).

Table 1. Determined acid numbers for olive oils

\begin{tabular}{c|c|c|c|c}
\hline & \multicolumn{5}{|c}{ Olive oil } \\
\cline { 2 - 5 } & Ifri & Khongue & Ohedjidid & Tourough \\
\hline $\begin{array}{c}\text { Acid number, } \\
\mathrm{mg} \mathrm{KOH} / \mathrm{g}\end{array}$ & 6.61 & 1.76 & 4.91 & 18.01 \\
\hline
\end{tabular}

${ }^{1} \mathrm{H}$ NMR spectra of various oils have typical regions which allow one to determine the overall amount of unsaturated fatty acids in triglycerides [23,24]. The positions of ones are areas between 2.7-2.9 and 5.2-5.5 ppm.

The ${ }^{1} \mathrm{H}$ NMR spectra of Ifri, Khongue, Ohejidid, Tourough oils were also similar to the IR spectra of these oils. However, the ${ }^{1} \mathrm{H}$ NMR spectrum of Tourough oil (Fig. 3) differs from the spectra of other oils exclusively in the intensity and integration of NMR signals. The signals at 2.7-2.9, 4.1-4.4 and 5.2-5.5 ppm belong to $\boldsymbol{d}, \boldsymbol{a}$ and $\boldsymbol{b}+\boldsymbol{c}$ protons, respectively (see Fig. 11).

The comparison of all four spectra of the investigated oils demonstrate that the Tourough oil contains more unsaturated acids than the Ifri, Khongue and Ohejidid oils.

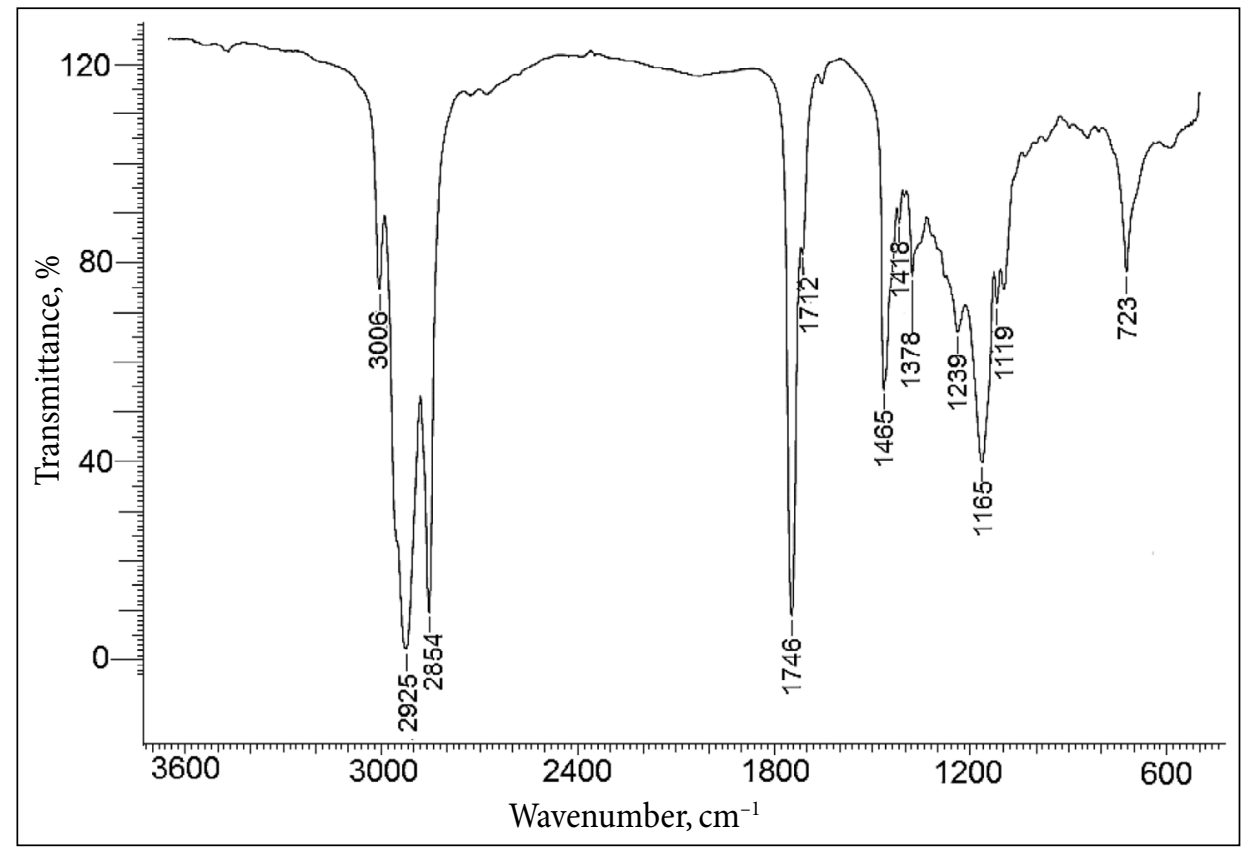

Fig. 2. IR spectrum of Tourough oil 


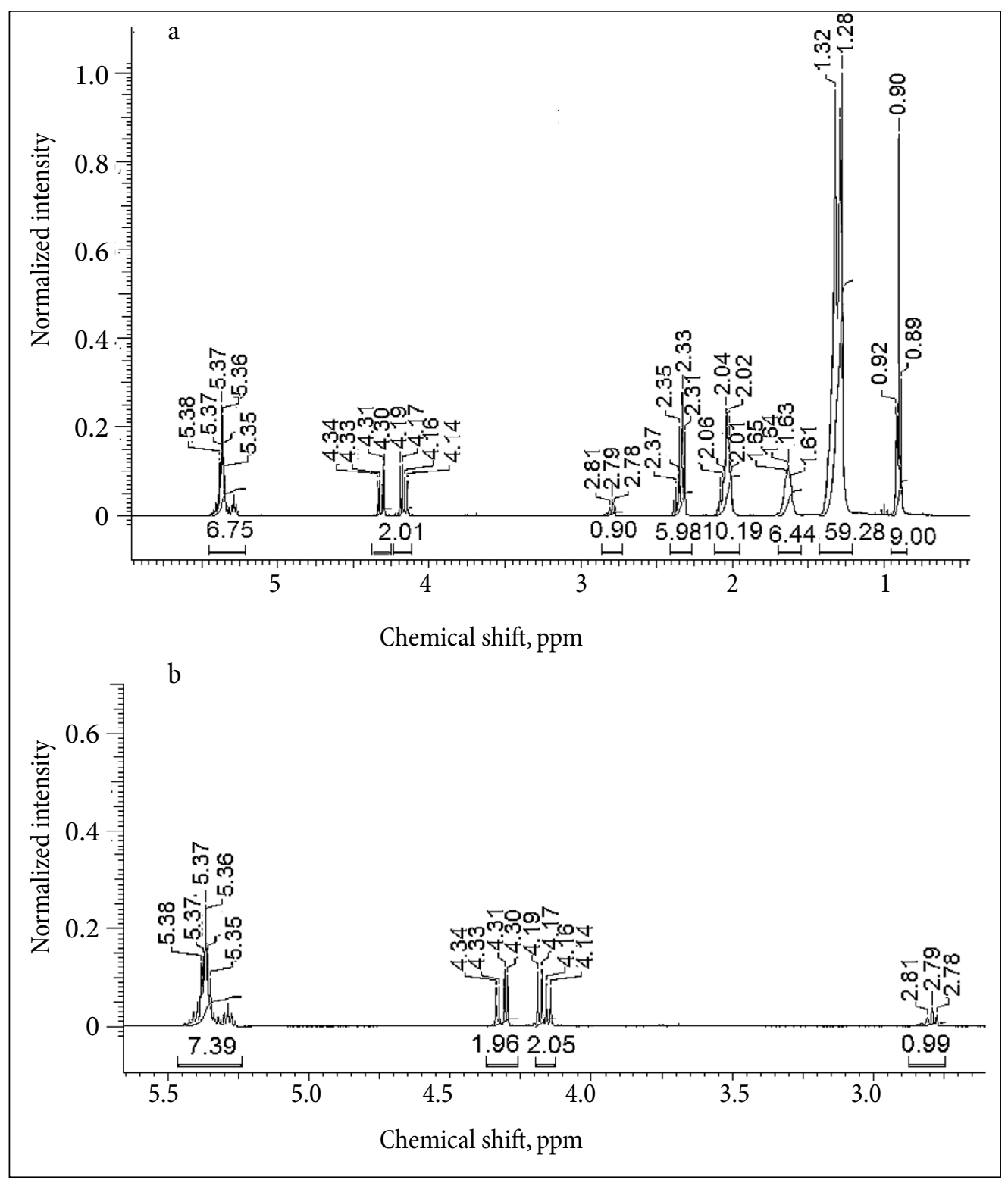

Fig. 3. The ${ }^{1} \mathrm{H}$ NMR spectrum of Tourough oil ( $\left(\mathrm{CCl}_{3}\right)$ : (a) is the whole spectrum; $(\mathrm{b})$ is the expanded part of the spectrum

It validates the values of integrals of the above-mentioned signals at 2.7-2.9 and 5.2-5.5 ppm (see Table 2).

Table 2. Integrated values of $1 \mathrm{H}$ NMR spectra

\begin{tabular}{ccc}
\hline Oil & Integral at 2.7-2.9 ppm & Integral at 5.2-5.5 ppm \\
\hline Ifri & 1.01 & 7.18 \\
\hline Khongue & 0.83 & 6.95 \\
\hline Ohejidid & 0.64 & 6.97 \\
\hline Tourough & 0.99 & 7.39 \\
\hline
\end{tabular}

This result indicates the fact that the Tourough oil consists of saturated palmitic and/or stearic acids and unsaturated oleic and linoleic acids except linolenic acid. Such conclusion followed from the ${ }^{13} \mathrm{C}$ NMR spectra of the explored oils.
The characteristic signal for linolenic acid in the ${ }^{13} \mathrm{C}$ NMR spectra for $\mathrm{C}(17)$ is located at $20.54 \mathrm{ppm}$. This signal was not found in all four ${ }^{13} \mathrm{C}$ NMR spectra of oils (Fig. 4), also the characteristic signals of $s p^{2}$ carbon atoms $(\mathrm{C}=\mathrm{C}$ double bonds of unsaturated fatty acids) are presented in the range of 130.3-127.8 ppm (evidently visible in Fig. 4b).

So it is possible to summarize that all results of the spectroscopic exploration of olive oils from Morocco (Tourough, Ifri, Khongue and Ohejidid localities) show small quantitative and qualitative differences between each other (the amount of free fatty acids and the composition of fatty acids in triglycerides). The spectroscopic data let unambiguously determine in general that main fatty acids in oils are saturated palmitic and/or stearic acids, unsaturated oleic and linoleic acids except linolenic acid; the highest amount of free fatty acids was detected in the oil from Tourough. 


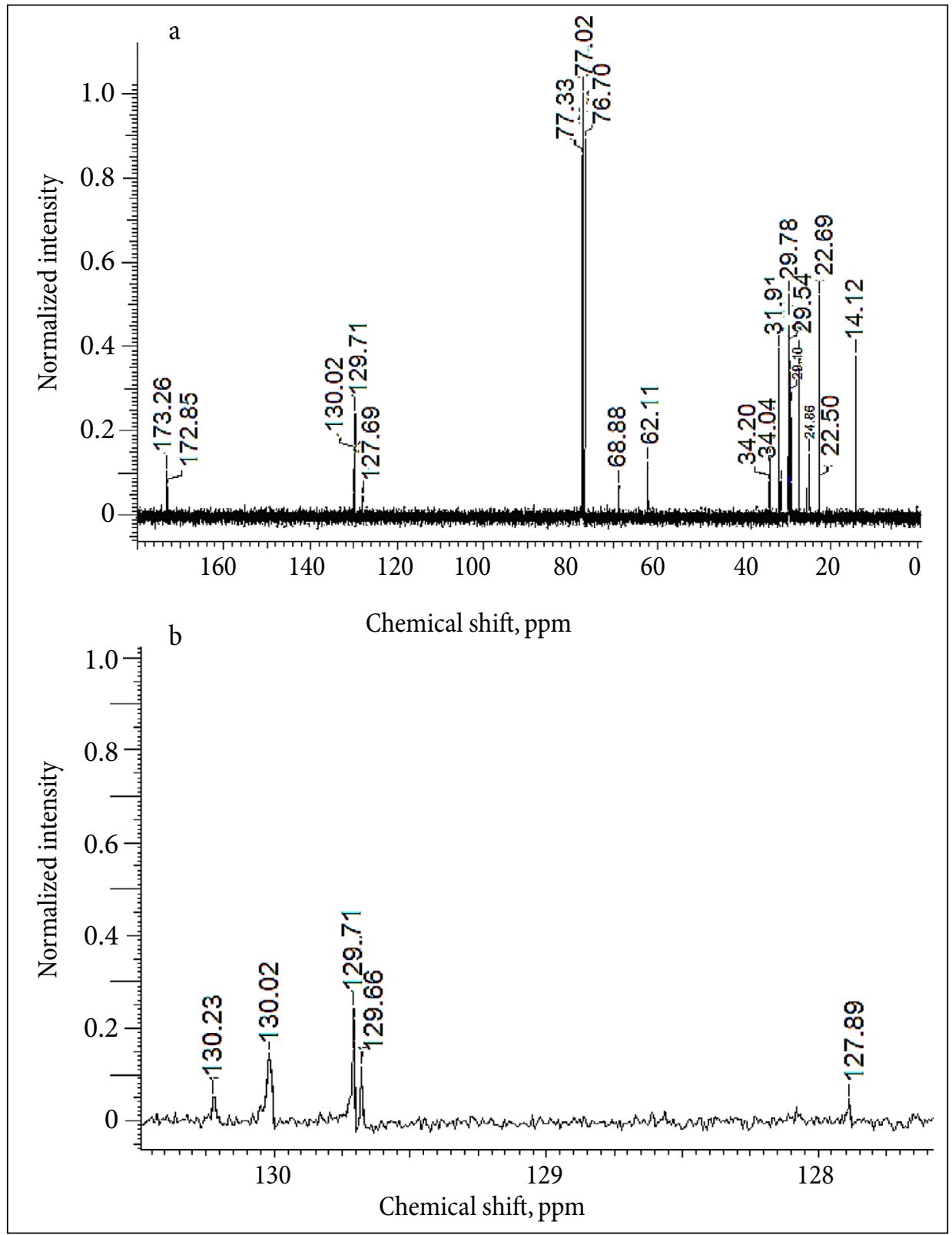

Fig. 4. The ${ }^{13} \mathrm{C}$ NMR spectrum of Tourough oil ( $\left(\mathrm{CCl}_{3}\right)$ : (a) is the whole spectrum; (b) is the expanded part of the spectrum

\section{Properties of oils and their films}

Notably, the unsaturated acids in the triglycerides make oil more polar, that explains the higher surface tension of Tourough oil - see Table 3. Also, unsaturated acids and material possessing a higher polarity supposes a stronger interaction between molecules that result in a slightly higher density - see Table 3 .

\section{Table 3. The density and surface tension of investigated olive oils}

\begin{tabular}{ccc}
\hline Olive oil & Density, $\mathbf{g} / \mathbf{c m}^{\mathbf{3}}$ & Surface tension, $\mathbf{~} \mathbf{N} / \mathbf{m}$ \\
\hline Khanque & 0.90 & 31.9 \\
\hline Touroug & 0.98 & 36.5 \\
\hline Ohedjdid & 1.02 & 35.7 \\
\hline Ifri & 0.92 & 33.9 \\
\hline
\end{tabular}

An important characteristic is a contact angle that relates to the thermodynamic work of adhesion. Work of adhesion is the reversible work required (per area unit) to separate the liquid from the solid leaving an adsorbed film in equilibrium with the saturated vapour of the liquid on the solid surface. Work of oil adhesion to steel is important concerning corrosion properties of oils in the presence of water. Thermodynamically, a relation of the free energy of adhesion per unit area of a solid-liquid pair is equal to the work $\left(W_{s l}\right)$ required to separate the unit area of the solid-liquid interface:

$$
W_{s l}=\gamma_{l v}(1+\cos \Theta) \text {. }
$$

Here $\gamma_{l v}$ is the surface tension of oil, $\Theta$ is the contact angle of oil on a solid substrate. 
As it is shown in Fig. 5, the calculated works of adhesion of oil on steel are similar, but lower than that for water. It means that in the presence of water the oils film will be displaced by water, and metals will corrode. Further corrosion measurements had been performed using carbon steel (ST3) as a substrate. The data obtained by electrochemical impedance spectroscopy (EIS) confirm a highly porous structure of the oil film.

Indeed, EIS is particularly well suited to evaluate the films and corrosion behaviour of materials whose surfaces have been coated with insulation films, because this method is a non-destructive method. In this study, experiments were carried out in order to determine the effect of the oil film on the impedance characteristics of surfaces and the differences in the corrosive behaviour. The typical Bode and Nyquist plots obtained for bare iron and iron coated by olive oil films are shown in Fig. 6. As it is seen, the Bode plots obtained for bare and coated iron differ and these differences could be described by different equivalent electrical circuits. The EI
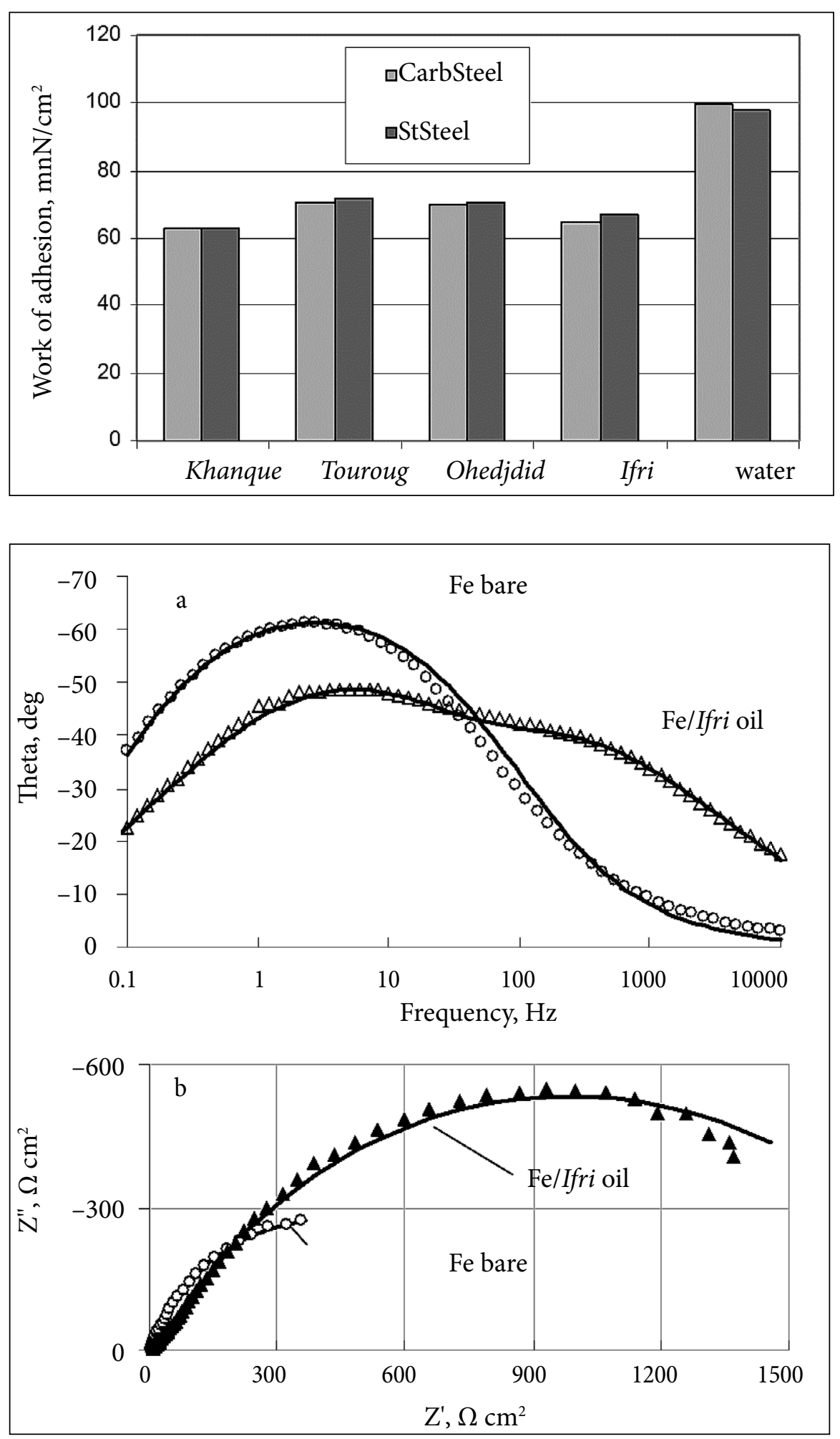

Fig. 5. Works of adhesion of the olive oils on carbon (CarbSteel) and stainless steel (StSteel)
Fig. 6. The typical Bode (a) and Nyquist (b) plots obtained for bare iron and iron coated by an oil film; points to the experimental data, a solid line is fitting to the equivalent circuits shown in Fig. 7: circuit (a) for Fe, circuit (b) for Fe coated by an oil film 
spectrum for Fe-bare shows one time constant, and could be described by a simple circuit shown in Fig. 7 a, whereas the EI spectra obtained for Fe coated by various olive oils contain rather two time constants.

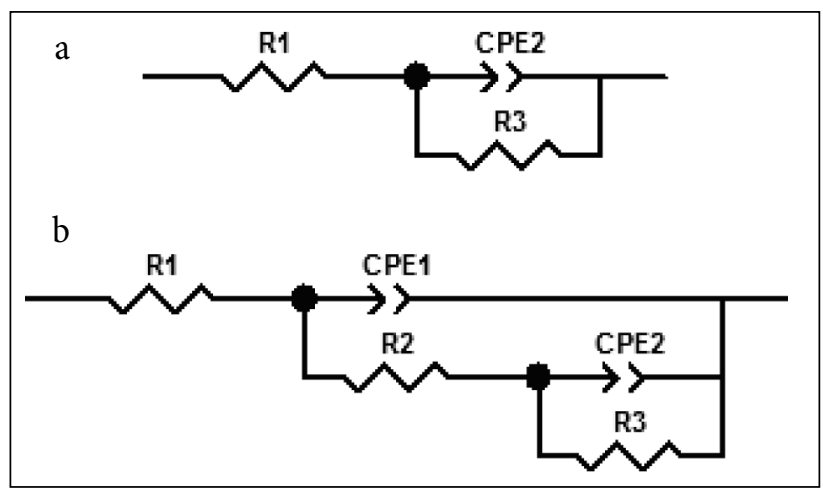

Fig. 7. Equivalent circuits used to fit the experimental ElS data obtained in corrosion media using a bare electrode (a), and electrodes coated by oil films (b). $\mathrm{R} 1$ represents the solution resistance, $\mathrm{R} 2$ and the constant phase element CPE1 represent the resistance and the capacitance of the oil film, respectively, whilst the resistance $\mathrm{R} 3$ and $C P E 2$ elements correspond to the bare metal/solution interface

There is a broad agreement about two time constants model used to describe a porous or defective insulating film on the metal, which is one of the main applications of EIS in this study. On the other hand, non-porous films typically exhibit one time constant at least during the early stage exposure [25. As it is shown in Fig. $7 b$, in the presence of oil on the electrode the both real $\left(Z^{\prime}\right)$ and imaginary (Z”) parts of impedance increase sufficiently in comparison with the EI spectra obtained for the bare electrode. However, in the cases of all oils films the values of $\mathrm{R} 2$ are 10-40 times less than R3. It means that the oil film is porous as follows from the determined values of its adhesion work (see Fig. 5).

In order to determine the corrosion currents in the absence and presence of oil films the anodic and cathodic branches of polarization curves were recorded in the electrode potential range from -0.5 to $+0.5 \mathrm{~V}$ versus the corrosion potential at the scan rate $2 \mathrm{mV} / \mathrm{s}$. The corrosion current densities were determined by extrapolation of cathodic and anodic parts to the corrosion potential. The determined corrosion current densities are shown in Fig. 8. The values of inhibition efficiency (IE) are also indicated in Fig. 8. This parameter was evaluated based on the determined corrosion current densities using the following expression [26]:

$$
I E=\frac{I_{c o r r}^{\text {bare }}-I_{\text {corr }}^{\text {film }}}{I_{\text {corr }}^{\text {bare }}} \cdot 100 \%
$$

Here $I_{\text {corr }}^{\text {bare }}$ and $I_{\text {corr }}^{\text {film }}$ are the corrosion densities of the bare and coated working electrode, respectively.

As it is seen, the corrosion currents on the film coated by olive oils are smaller only 2-3 times in comparison with bare $\mathrm{Fe}$, and those values make inhibition efficiency at $57-75 \%$. As follows from the corrosion study, the evident correlation between the chemical composition of olive oil and the corrosion behaviour of steel coated by the oil film was not detected.

\section{Tribological properties}

The tested olive oils from different regions have quite similar lubricating properties (Fig. 9): both the wear reduction and the friction coefficient have a similar variation tendency.

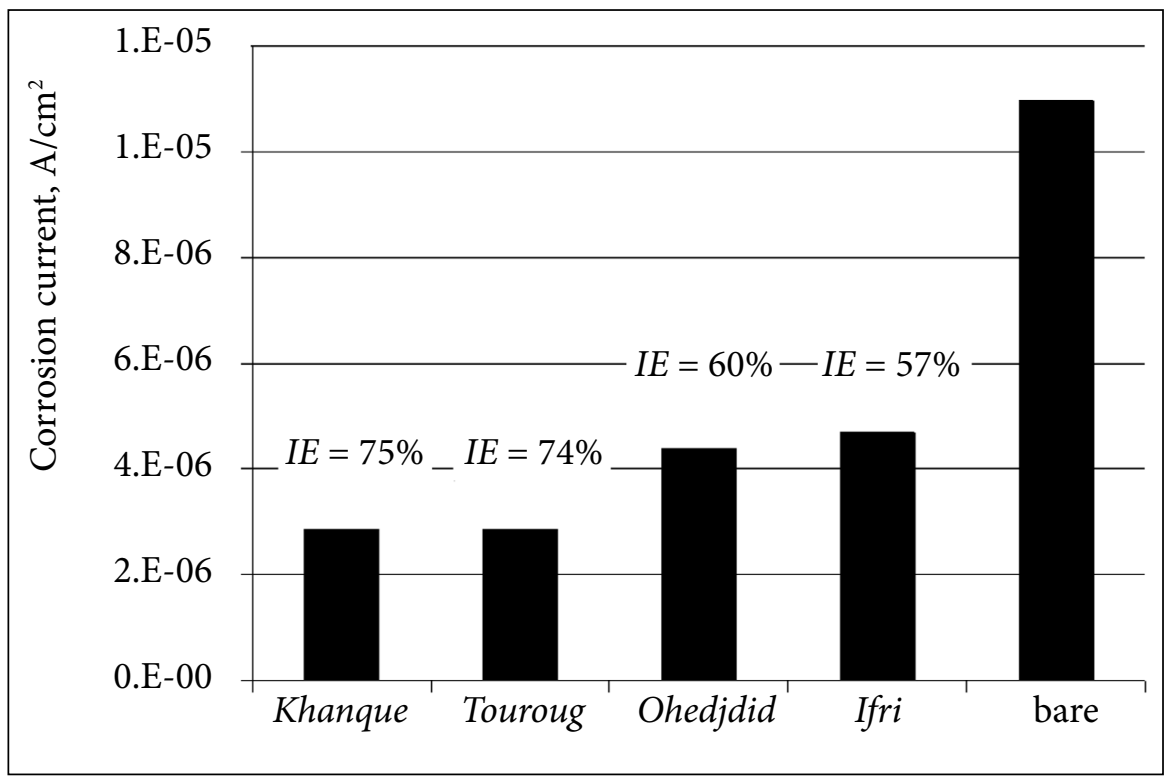

Fig. 8. The corrosion currents and inhibition efficiencies (IE) obtained for bare Fe and Fe coated by various olive oils 


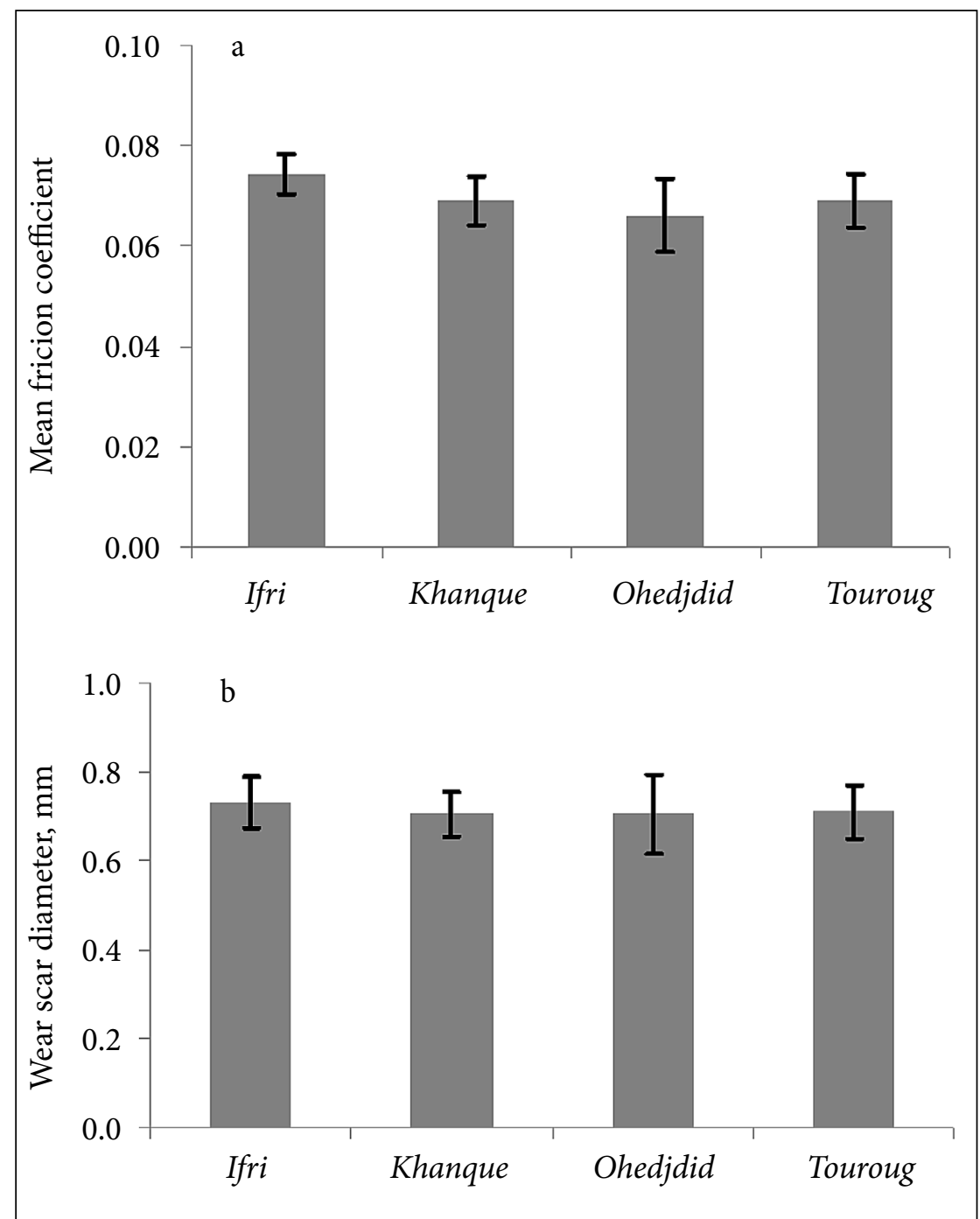

Fig. 9. The mean friction coefficients (a) and the wear (b) of tested olive oils

However, the Ohedjdid oil has the lowest mean friction and wear, while the Ifri oil has the highest. The difference can be explained by a different fatty acid structure of the investigated olive oils. A higher amount of saturated fatty acids can lead to a better molecule adsorption on lubricating surfaces, and consequently shows better lubricating properties. The free fatty acids can have an even higher effect on lubrication properties. However, despite that IR spectroscopy showed that the Tourough oil has the highest value of free fatty acids, it does not show any difference in the tribological behaviour. On the other hand, the Ohedjdid and Tourough oils have a higher value of adhesion work and consequently a higher stability of the lubrication film than the Ifri oil. This can explain slightly worse tribological characteristics of the Ifri oil.

One of the specific characteristic of all the investigated olive oils is friction continuously decreasing during the test (see Fig. 10). At the onset the friction rises sharply and after a certain time begins to decrease and goes down till the end of the test. The more intense initial friction is related to the run-in stage. It takes $500 \mathrm{~s}$ to stabilize friction variation and reach a steady state regime. Such friction pattern can be caused by free fatty acids and mono-, diglycerides. Caused by wear of the balls the contact area increases, leading to lower pressure. The polar molecules adsorbed on the interacting surfaces can withstand only lower loads. Therefore, the contact area increasing during the test leads to better conditions for an adsorbed layer to form, consequently the decreasing friction is observed. The Ifri oil shows not only a higher average value of the friction coefficient (Fig. 9a), but also its running-in period lasts longer and on a higher level of the friction coefficient. In this case the oxidation stability could play an important role.

It is generally well known that vegetable oils have pure oxidation stability. The oxidation stability test results, expressed by the induction period, are presented in Fig. 11 . There is a great difference in the oxidation stability between the investigated olive oils. The Ifri olive oil has the lowest oxidation stability having the induction period of only 2 hours. This result is in line with the lubrication results where the Ifti 


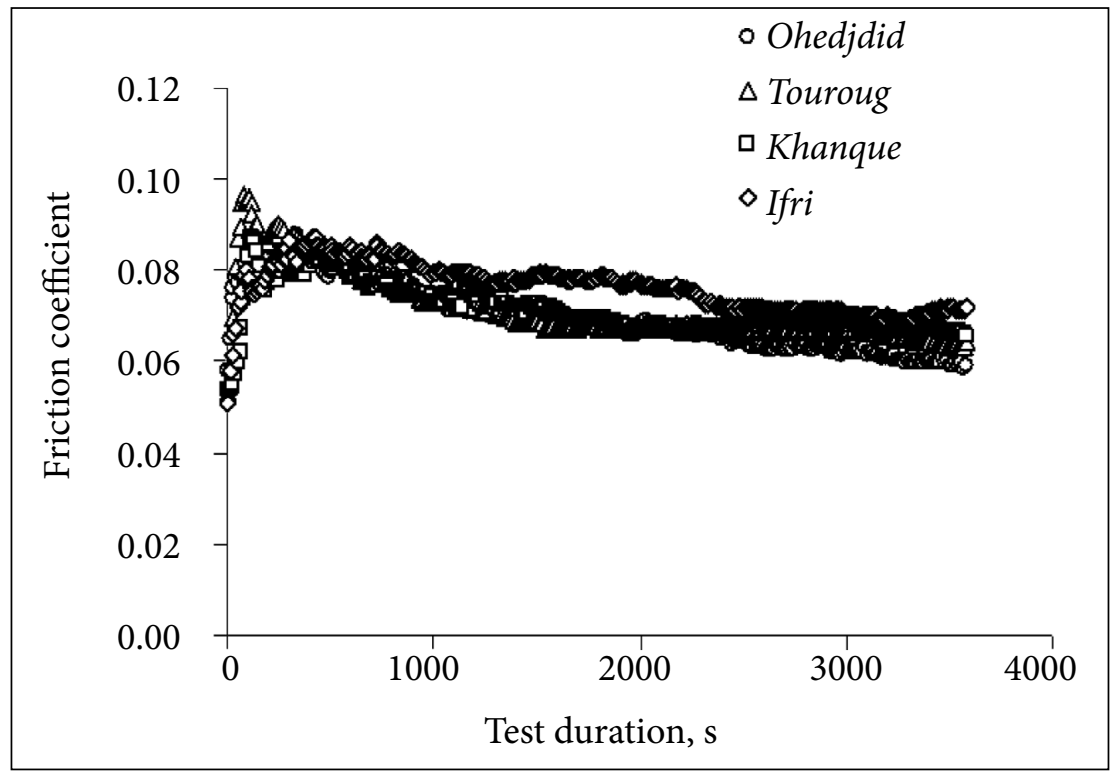

Fig. 10. The variation of the friction coefficient during the test of various olive oils

oil showed the worst lubrication ability. The unsaturated and even polyunsaturated fatty acids cannot adsorb on the surface as close as saturated ones can and consequently cannot ensure good lubricating properties [27]. During oxidation, unsaturated fatty acids lead to fast oil oxidation, reducing the induction period. Moreover, the oxidation of the olive oil leads to decreasing the lubrication ability. The oxidation products, such as peroxides, ketones, high molecular weight products, epoxides etc., contaminate the oil increasing its acidity, viscosity, corrosiveness and decreasing the viscosity index [28]. The Tourough olive oil has the longest induction period $(5 \mathrm{~h})$ as well as the highest oxidation stability. Its tribological properties were somehow near the best probably due to the highest content of free fatty acids. Actually, the oxidation is an obstacle for a wider vegetable oil usage as a lubricant, its stabilization is one of the main goals, therefore oils having a higher stability are more preferable.

The copper strip corrosion test is designed to assess the relative degree of corrosivity of a petroleum product. Copper corrosion limits provide assurance that difficulties will not be experienced in deterioration of the copper and copper-alloy fittings and connections that are commonly used in many types of utilization, storage, and transportation equipment. The mechanism of copper corrosion differs from the mechanism of steels: copper corrosion undergoes the oxygen depolarization mechanism while steels undergo the hydrogen depolarization mechanism that supposes higher corrosion rates. In the case of copper, this corrosion test provides an additional information about oil possibility to oxidize the metal. The copper strip corrosion test showed that the tested olive oils had low corrosiveness. They all

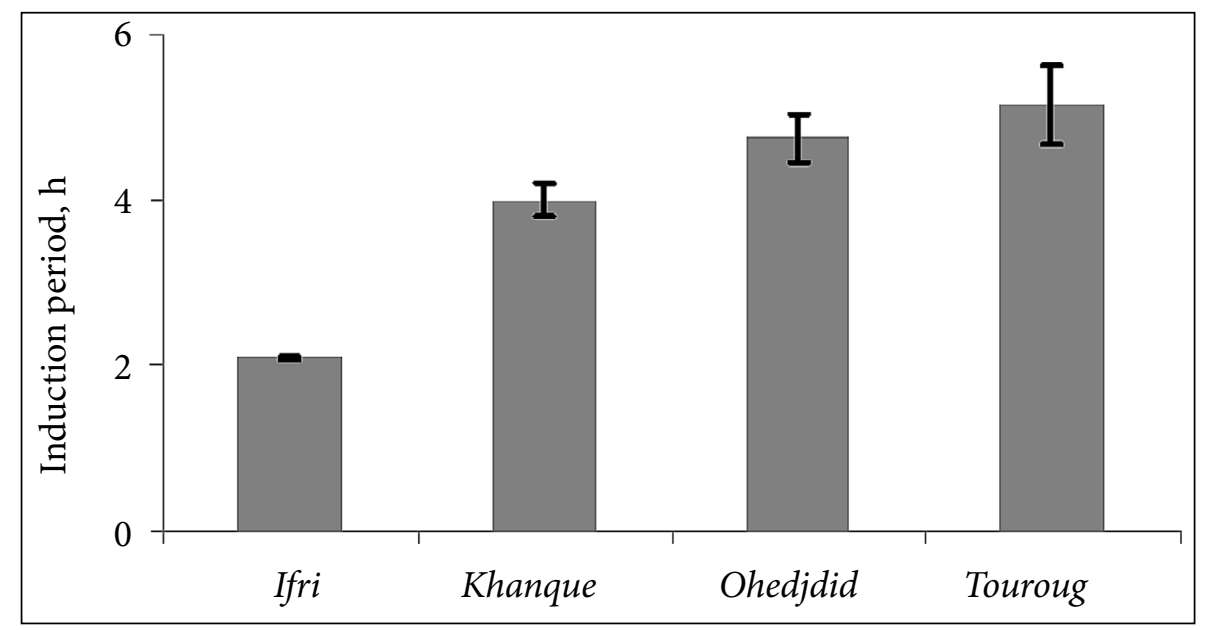

Fig. 11. The oxidation stability of the investigated olive oils 
have the slight corrosion class - 1a. It is the lowest corrosiveness class which fully satisfies the requirements for environment-friendly lubricants.

\section{CONCLUSIONS}

1. All results of the spectroscopic exploration of olive oils from Maroc (from Tourough, Ifri, Khongue, Ohejidid districts) show small quantitative and qualitative differences between each other (the amount of free fatty acids and the composition of fatty acids in triglycerides). The spectroscopic data let us unambiguously determine that the main fatty acids in oils are saturated palmitic and/or stearic acids, unsaturated oleic and linoleic acids except linolenic acid. Based on the IR data, the highest amount of free fatty acids was detected in the oil from Tourough.

2. The contact angle and work of adhesion values complemented with the electrochemical impedance spectroscopy data show that all olive oil films on the steel surfaces are porous; therefore, the values of corrosion inhibition efficiency are relatively low and ranged from 57 to $75 \%$.

3. The lower value of adhesion and consequently the lower stability of the lubrication film, and also the lower oxidation stability of some kinds of olive oils (ex. Ifri) can explain the worse tribological properties (higher wear and friction, lower stability of the friction coefficient). This difference is related to decreasing lubrication ability because a higher amount of unsaturated fatty acids causes a lower adsorption ability on the surface compared with that of saturated fatty acids. On other hand, the oxidation stability can be most important for the tribological application of olive oils. The oils with the highest oxidation stability (Tourough and Ohejidid) show better tribological properties.

\section{ACKNOWLEDGEMENTS}

The authors acknowledge funding from the FP7 Project Oil \& Sugar (295202).

Received 5 August 2017 Accepted 8 January 2018

\section{References}

1. R. M. Balestra, A. M. G. Castro, et al., Surf. Coat. Technol., 205, S79 (2011).

2. S. A. Lawal, I. A. Choudhury, Y. Nukman, Int. J. Mach. Tools Manuf., 52, 1 (2012).

3. B. Ozcelik, E. Kuram, M. H. Cetin, E. Demirbas, Tribol. Int., 44, 1864 (2011).

4. Y. M. Shashidhara, S. R. Jayaram, Tribol. Int., 43, 1073 (2010).
5. Biodegradable Oils - How to Apply and Maintain [http:// www.machinerylubrication.com/Read/511/biodegradableoils.

6. A. Ruggiero, R. D’Amato, M. Merola, P. Valasek, M. Muller, Tribol. Int., 109, 529 (2017).

7. A. J. B. Sutton, D. J. Sapsford, J. Environ. Eng., 142(1), Article No. 04015057 (2016).

8. S. Arumugam, G. Sriram, R. Ellappan, Energy, 72, 618 (2014).

9. J. Padgurskas, R. Rukuiža, A. Kupčinskas, R. Kreivaitis, Ind. Lubr. Tribol., 67(6), 557 (2015).

10. R. Kreivaitis, M. Gumbyte, K. Kazancev, J. Padgurskas, V. Makarevičiene, Ind. Crops Prod., 43, 511 (2013).

11. Understanding Food-Grade Lubricants http://www.machinerylubrication.com/Read/445/food-grade-lubricants.

12. L. Honary, E. Richter, Biobased Lubricants and Greases: Technology and Products, John Wiley \& Sons (2011).

13. D. R. Kodali, Ind. Lubr. Tribol., 54, 165 (2002).

14. A. Suzuki, R. Ulfiati, M. Masuko, Tribol. Int. 42, 987 (2009).

15. J. Tous, L. Ferguson, in: J. Janick (ed.), Progress in New Crops, ASHS Press, Arlington, VA (1996).

16. G. Beltran, C. Del Rio, S. Sanchez, L. Martinez, J. Agric. Food Chem., 52, 3434 (2004).

17. Composition of Foods Raw, Processed, Prepared. USDA National Nutrient Database for Standard Reference [http:// ndb.nal.usda.gov).

18. S. J. Asadauskas, J. M. Perez, in: S. Z. Erhan, J. M. Perez (eds.), Biobased Industrial Fluids and Lubricants, AOCS Press, Champaign, Illinois (2002).

19. P. L. Menezes, M. R. Lovell, M. A. Kabir, C. F. Higgs III, P. K. Rohatgi, in: M. Nosonovsky, B. Bhushan (eds.), Green Tribology, Green Energy and Technology, 265-286, Springer-Verlag, Berlin Heidelberg (2012).

20. J. Padgurskas, R. Rukuiža, A. Meškinis, R. Kreivaitis, B. Spruogis, Transport, 1, 56 (2016).

21. H. Cesiulis, N. Tsyntsaru, Proceedings of International Conference Balttrib'2009, Kaunas (2009).

22. DIN 51350-3: 2015, Testing of lubricants - Testing in the four-ball tester - Part 3: Determination of wearing characteristics of liquid lubricants.

23. M. S. F. Lie Ken Jie, C. C. Lam, Chem. Phys. Lipids, 77, 155 (1995).

24. G. Vlahov, A. D. Shaw, D. B. Kell, J. Am. Oil Chem. Soc., 76, 1223 (1999).

25. G. S. Frankel, J. Test. Eval., 42(3), 517 (2014).

26. N. Kuriakose, J. T. Kakkassery, V. P. Raphael, S. K. Shanmughan, Indian J. Mater. Sci., 2014, Article ID 124065 (2014).

27. S. M. Hsu, R. S. Gates, Tribol. Int., 38, 305 (2005).

28. N. J. Fox, G. W. Stachowiak, Tribol. Int., 40, 1035 (2007). 
Henrikas Cesiulis, Albinas Žilinskas, Juozas Padgurskas,

Raimondas Kreivaitis, Raimundas Rukuiža

İVAIRIŲ ALYVUOGIŲ ALIEJŲ CHEMINIAI,

ELEKTROCHEMINIAI BEI TRIBOLOGINIAI

TYRIMAI IR JŲ ELGSENA ANT PLIENO

Santrauka

Tirta įvairiuose Maroko regionuose pagamintų skirtingo rūgštingumo alyvuogių aliejų pavyzdžių cheminès sudètys ir fizinès savybès, jų itaka tribologinėms ir antikorozinèms charakteristikoms. Cheminè sudètis nustatyta naudojant IR, ${ }^{1} \mathrm{H}$ ir ${ }^{13} \mathrm{C}$ BMR spektroskopijos metodus. Tirtų aliejų cheminè sudètis skiriasi nedaug (laisvụjų riebiųjų rūgščių kiekis ir jų sudètis trigliceriduose). Vienareikšmiškai nustatyta, kad riebiosios rūgštys aliejuose yra palmitino ir / arba stearino rūgštys, nesočiosios - oleino ir linolo rūgštys. Ivvertintas aliejų stabilumas oksidacijai. Ribinio kampo matavimo ir elektrocheminio impedanso spektroskopijos metodais nustatyta, kad aliejaus plèvelès ant plieno yra poringos, todèl korozijos inhibavimo efektyvumas siekia 27-75\%. Ivertinti trinties koeficientai, aptariamas suteptų paviršių dilumas. 
